Military Technical College

Kobry El-Kobbah,

Cairo, Egypt

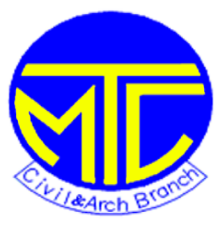

$9^{\text {th }}$ International Conference on Civil and Architecture

Engineering

ICCAE-9-2012

\title{
Effect Of Cross Ribs and Rigidity Of Middle Supports on the Behavior Of One Way Ribbed Slabs
}

M. H. Ahmed ${ }^{\star}$, Y. A. Hassaneen ${ }^{\star}$, Z. E. Abd El Shafy* And M. A. Farouk ${ }^{\star \star \star}$

\section{Abstract}

The effect of cross ribs and the rigidity of middle supports on the behavior of one way ribbed slabs were introduced in this paper. The 3D-FEM model through (ANSYS) program has been used to accomplish this study. The ultimate load, the cracking load, the strain of concrete, stress of steel and deflection of the analyzed slabs were calculated as well as mode of failure was observed. The optimum reinforcement, cross section and the location of cross rib as well as the effect of middle beam on the behavior of slabs were concluded.

\section{Keywards:}

cross ribs, way ribbed slabs, 3D-FEM model, The ultimate load, cracking load, mode of failure

\section{1-Introduction}

The ribbed slabs are common types of slabs. The main advantages of using ribbed slabs are permitting a given minimum clear height to be maintained with a reduced overall story height, covering a big horizontal area, simple formwork and reduced own weight. The system exhibits higher stiffness and smaller deflections.

The Egyptian code recommends with using cross ribs "one to three ribs " in one way ribbed slab when the length of these slabs are greater than $5 \mathrm{~m}$ to decrease the deflection of slab without taking into account the effect of cross ribs on the behavior of main ribs

Soghair H.M et-al (2008) based on linear analysis concluded that the cross ribs have pronounced effect on the behavior of slabs. And the existence of these ribs decreases the produced B.M in the main ribs.

In continuous ribbed slabs with hidden or appearance beams, the designers considered that these beams are as rigid support without existence any difference

*Professor civil Eng. Dept., Faculty Of Eng., Assiut University

** Lecturer, Civil Eng. Dept., Assiut University.

***Engineer Expert in Ministry Of justice.

between them on the behavior of slabs. Continuous one way ribbed slabs were 
analyzed in this work by using finite element theory through ANSYS program. The used models illustrated the effect of cross ribs and rigidity of middle supports on the behavior of one way ribbed slab.

\section{2- Numerical Study}

\section{1 constitutive model}

\section{Concrete Constitutive Model}

Solid65, an eight node solid element, is used to model the concrete with or without reinforcing bars. The solid element has eight nodes with three degrees of freedom. The element is capable of having plastic deformation, cracking in three orthogonal directions, and crushing. The geometry and node positions for this element type are shown in Fig (1).

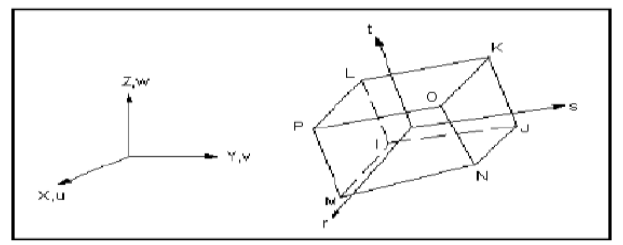

Fig 1. Solid 65-3D reinforced concrete element

The input data are elastic modulus $\left[E_{c}\right]$,Ultimate uniaxial compressive strength $\left[f_{c}^{-}\right]$ ultimate uniaxial tensile strength [modulus of rapture $\left[f_{r}\right]$ Poisson's ratio $(v)$, density ( $\gamma)$, shear transfer coefficient for an open crack $\left(\beta_{t}\right)$, shear transfer coefficient for a close crack $\left(\beta_{c}\right)$ and compressive uniaxial stress strain relationship of concrete.

The elastic modulus of elasticity is obtained by the pulse velocity method and can be calculated by means of its ultimate concrete compressive strength by using Equation (1) ACI_318 [2]

$$
f_{c}^{\prime}=\left[\frac{E \varepsilon_{c}}{4730}\right]^{2}
$$

Where:

$\left[f_{c}^{-}\right]$Ultimate compressive strength of concrete in MPa.

The tensile strength of concrete is $8-15 \%$ of the compressive strength Shah, et al 1995[8]. A typical stress- strain curve for concrete is shown in Fig (2) Bangash $1989[2]$.

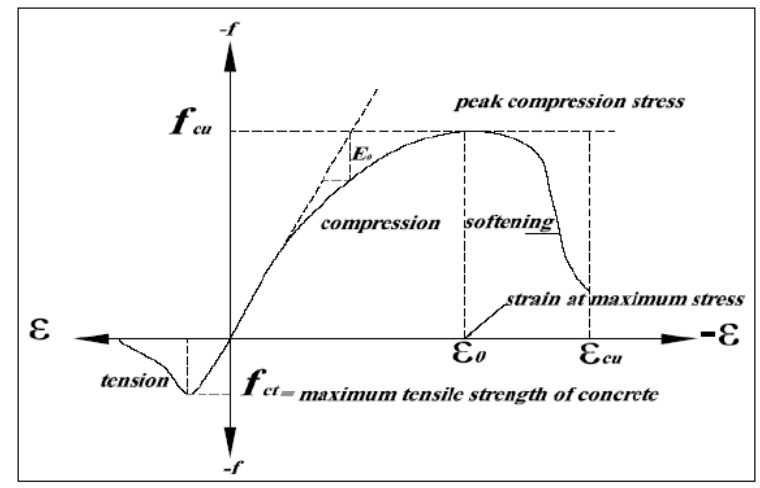


Fig 2. Typical uniaxial compressive and tensile stress-strain curve for concrete (Bangash 1989).

Numerical expressions of Desayi and Krishnan 1964 [6] ,Equations (2) and (3) are used to construct the uniaxial compressive stress-strain curve for concrete.

$$
\begin{aligned}
& f=\frac{E_{C} x \varepsilon}{1+\left(\frac{\varepsilon}{\varepsilon_{0}}\right)} \\
& \varepsilon_{0}=\frac{2 f_{c}^{\prime}}{E_{c}} \\
& E_{c}=\frac{f}{\varepsilon^{2}} \\
& f \quad=\text { stress at strain } \varepsilon, \text { in } \mathrm{MPa} \\
& \varepsilon \quad=\text { strain at stress } f \\
& \varepsilon_{0} \quad=\text { strain at the ultimate compressive strength. }
\end{aligned}
$$

The values of the considered parameters are presented in table 1

Table 1

\begin{tabular}{|c|c|c|c|c|c|}
\hline$\left[E_{c}\right] \mathrm{kg} / \mathrm{cm}^{2}$ & $(v)$ & $\left(\beta_{t}\right)$ & $\left(\beta_{c}\right)$ & {$\left[f_{c t}\right] \mathrm{kg} / \mathrm{cm}^{2}$} & {$\left[f_{c}^{-}\right] \mathrm{kg} / \mathrm{cm}^{2}$} \\
\hline $2.0 \mathrm{E}^{5}$ & 0.2 & 0.2 & 0.5 & 25 & 250 \\
\hline
\end{tabular}

\section{Reinforcement constitutive model}

The reinforcement has been modeled as a discrete reinforcement (Link8) throughout the element (solid65).

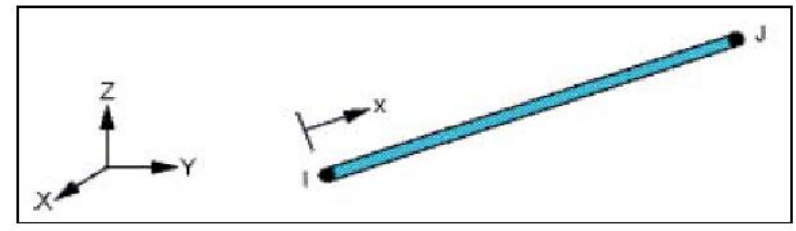

Fig. 3 8-3D bar element.

The element is capable of having plastic deformation, stress stiffening, and large deflection. The geometry, node positions, and the coordinate system for this element are shown in Fig (3). The considered steel reinforcement was typical grade 360/520 with Poisson's ratio 0.3. The steel was assumed elastic-perfectly plastic material (Bilinear Isotropic Hardening) and identical in tension and compression. These options used the von Mises yield criterion with the associated flow rule and isotropic work hardening. Fig (4) shows stress-strain relationship used in this study.

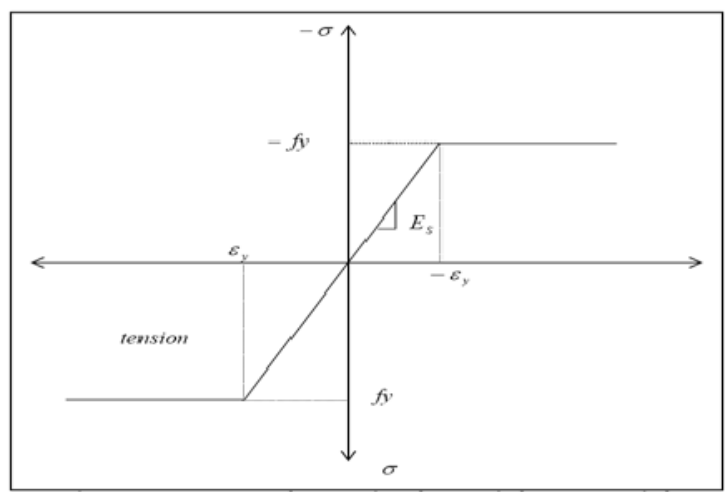


Fig 4. Steel stress-strain relationship used in this study.

\subsection{Geometrical modeling}

- Only one quarter of the model was solved due to symmetry.

- The uniform load applied on slabs was taken as a concentrated load at the intermediate point of each element.

- The pressure applied on slabs was taken as a concentrated load at the intermediate point of each element. Fig (5) illustrates the applied loading.

- The symmetry boundary conditions were set first. The model being used was Symmetrical about two planes. The boundary conditions for both planes of symmetry are shown in Fig (6).
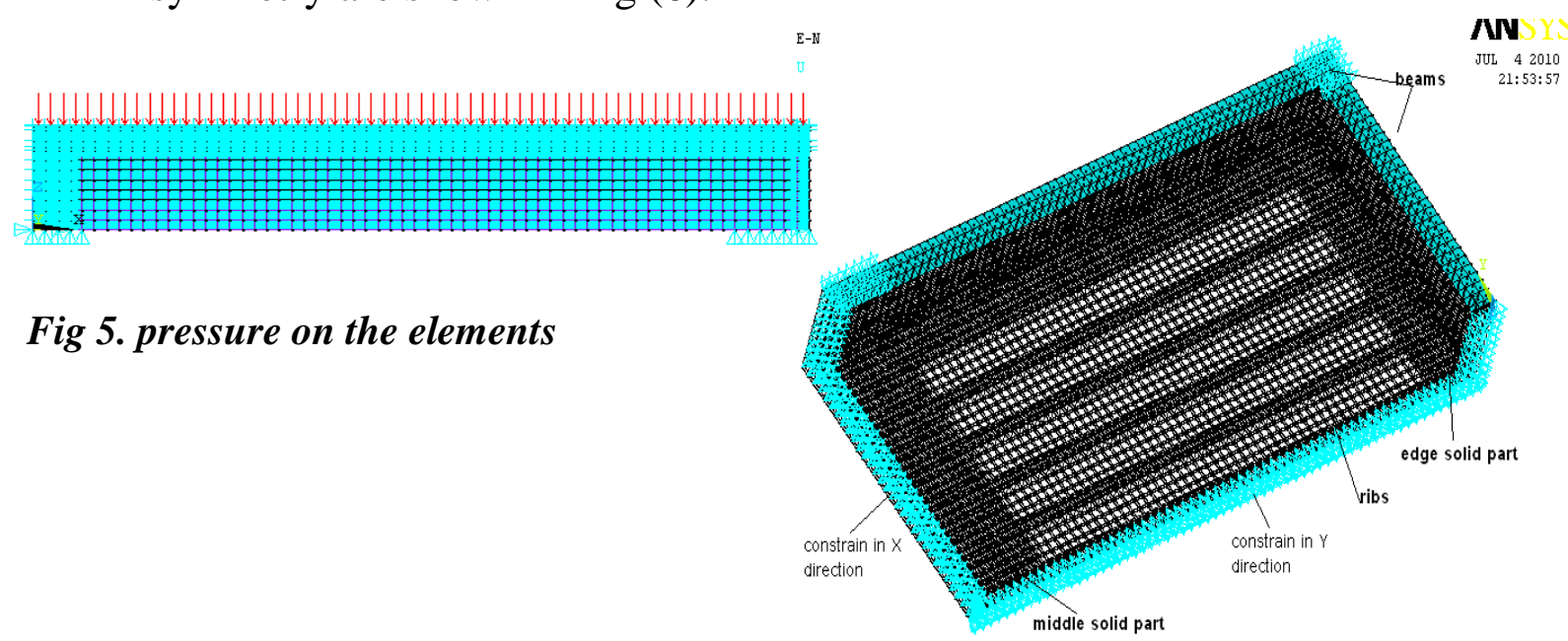

Fig 5. pressure on the elements

\subsection{Studied Parameters}

Fig 6. Boundary Condition for the model

One way ribbed slabs were analyzed by finite element method by using ANSYS program. The effect of the following variables were studied:-

- Cross ribs.

- The rigidity of middle supports.

Seven two bays one way slabs were analyzed to study these variables. The reference slab has dimensions $6 \times 6 \mathrm{~m}$ for each bay. The ribs had cross section $0.1 \times 0.25$ $\mathrm{m}$ and top slab thickness $0.05 \mathrm{~m}$. The net space between ribs was $0.4 \mathrm{~m}$. The width of middle solid part was $1.8 \mathrm{~m}$ and width of edge solid parts in each side was $0.3 \mathrm{~m}$. The supported beams have cross section $0.3 \times 1.05 \mathrm{~m}$. The tension reinforcement of the ribs were $(2 \Phi 16)$. The main reinforcement of middle solid part were (17Ф22) and compression steel was (10Ф22). Both top and bottom reinforcement of edge solid parts were $(3 \Phi 12)$.

\section{The analyzed slabs were divided into two groups as follows:-}

Group I: - The cross section and reinforcement of the cross rib as well as the position of cross rib were variable. The cross rib in slab I1 lies at the middle of slab and had the same section and reinforcement of main ribs. The cross rib of slabs I2, I3 and I4 had cross section $0.2 \times 0.25 \mathrm{~m}$ and main reinforcement $(2 \Phi 22)$. The position of cross rib 
for slabs I2, I3 and I4 were at distance $2.4 \mathrm{~m}$ "in middle of slab", $1.6 \mathrm{~m}$ and $0.7 \mathrm{~m}$ respectively from the middle of solid part.

Group H: - The middle solid part of this group was replaced with middle tee section beam. The depth of middle beam for slabs $\mathrm{J} 1$ and $\mathrm{J} 2$ were $0.75 \mathrm{~m}$ and $0.95 \mathrm{~m}$ respectively. The width of web of the beams was $0.2 \mathrm{~m}$ and the width of flange of these beams was $0.8 \mathrm{~m}$. The main reinforcement of beam (7Ф22) and the stirrup hanger steel was $(3 \Phi 18)$. The stirrups was $(10 \phi 10) / \mathrm{m}^{\prime}$ for distance $1 \mathrm{~m}$ from each support and $(5 \phi 8) / \mathrm{m}^{\prime}$ for the rest of the beam. The middle width of solid part was minimum and equals $1 \mathrm{~m}$.

\subsection{Results and discussion}

\subsubsection{The effect cross ribs}

\subsubsection{1)- cracking and ultimate loads, modes of failure.}

The cracking load for all slabs occurred at the mid section of cross rib. So it was observed that increase the reinforcement and cross section of the cross rib from slab I1 to slab I2 have pronounced effect on the cracking load. And the change of position of cross rib for slabs I2, I3 and I4 has small effect on the cracking load.

$\mathrm{P}_{\mathrm{cr}}$ of slabs I1, I2, I3 and I4 are $69.2 \%, 92.3 \%, 92.3 \%$ and $100 \% \mathrm{Pcr}$ of reference slab respectively. The relationship between position of cross rib from middle solid part and $\mathrm{P}_{\mathrm{cr}}$ is shown in Fig (7)

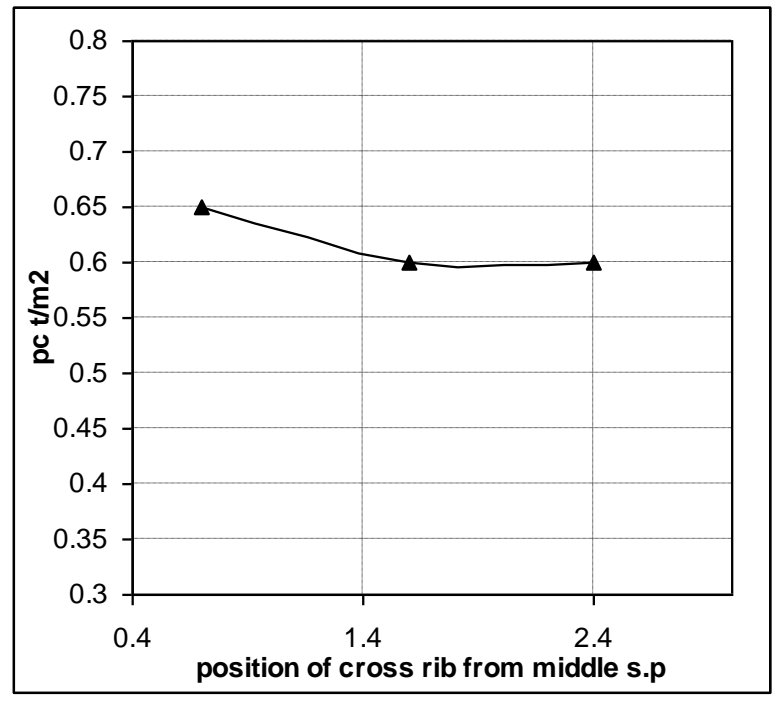

Fig (7) The relationship between positions of cross rib and Pcr

It was noted that the smallest value of cracking load of cross rib was in slab I1 because that the cross rib in this slab has small section and low reinforcement comparison with the loads on it. While the highest value of cracking load was in slab I4 where the cross rib is near from the middle solid part. This is because that the cross rib supported on the edge beams. The deflection of these beams is maximum at the middle and decreases as approaching from the supports and the rigidity of the beams is high at their ends. So as the cross rib supported near from the ends of the beam where in the same time approaches from the middle solid part, the restrain of the ends of the cross rib increase and the negative bending moments at the ends of the cross rib 
increase. This leads to decrease the positive bending moment at the middle of cross rib which causes the cracks. This illustrates the reason of the smallest value of cracking load in slab I4. Table 2 shows the stress of upper steel of the cross rib

Table 2

\begin{tabular}{|c|c|c|c|}
\hline slabs & $\left(\mathrm{I}_{2}\right)$ & $\left(\mathrm{I}_{3}\right)$ & $\left(\mathrm{I}_{4}\right)$ \\
\hline slabs of Group (I) & $\begin{array}{c}\text { C.R in the } \\
\text { middle } \\
\text { mode 2 }\end{array}$ & $\begin{array}{c}\text { C.R at } \\
1.6 \mathrm{~m} \text { from } \\
\text { S.P mode 2 }\end{array}$ & $\begin{array}{c}\text { C.R at O.7 } \\
\text { from S.P } \\
\text { mode 2 }\end{array}$ \\
\hline stress of upper steel of cross rib (t/m2) & 12500 & 14184 & 15200 \\
\hline
\end{tabular}

Where :

C.R :- cross rib

Mode (2) : the cross rib has cross section $0.2 \times 0.25 \mathrm{~m}$ and main reinforcements (2Ф22)

From investigation of table 2 , it was observed that as the cross rib supported approaching from the end of the edge beam, the stress of upper steel of cross rib increases. This means the negative bending moments increase as mentioned before.

The final modes of failure for slabs I2, I3, I4 were tension flexural failure caused by yielding of the tension reinforcement of middle solid part. While the final mode of failure for slab I1 was compression failure due to the principle stress at the bottom fibber of the connection between the cross rib and the edge solid part. And it was observed in this slab, before occurring the failure, the main reinforcement of the cross rib reached at the yielding. So, there was need to change the cross rib and its reinforcement, then study the position of cross rib.

It was observed that the ultimate load increases when the distance between the cross rib and middle solid part decreases from $2.4 \mathrm{~m}$ to $1.6 \mathrm{~m}$ and $0.7 \mathrm{~m}$. This is due to the fact that, the main ribs are supported on three supports, the edge beam, cross rib and middle solid part. And due to decrease the rigidity of middle solid part comparison with the rigidity of edge beam, the maximum section of the main rib lies in between the mid section of the rib and middle solid part. So as the cross rib approaches from the maximum zone of the main rib, the participate of cross rib for carrying the reactions of the main rib is higher. And this leads to decrease the stress of the main steel of the middle solid part and make the yielding to late.

Also, it was observed that the rate of increase the ultimate load was slightly when the distance between the cross rib and middle solid part decreases from $1.6 \mathrm{~m}$ to $0.7 \mathrm{~m}$. This indicates that the effect of position of the cross rib on the ultimate load is nearly constant when: $\quad 0.3 \mathrm{~L}^{\prime} \geq \mathrm{d}^{\prime} \leq 0.15 \mathrm{~L}$.

Where $L^{\prime}$ is the net span of the main rib, $=4.8 \mathrm{~m}$

$\mathrm{d}$ is the distance between the cross rib and middle solid part.

$\mathrm{Pu}$ of slabs I1, I2, I3 and I4 are 100\%, 113.4\%, 119.4 and $120.9 \% \mathrm{Pu}$ of reference slab respectively. The relationship between position of cross rib from middle solid part and $\mathrm{Pu}$ is shown in Fig (8).

\subsubsection{2)- Deformations and stress of the cross ribs}

From the load -strain and stress curve of the cross rib of slab I1. It was noted that the main reinforcement of the cross rib reached to the yielding at load 
$2.9 \mathrm{t} / \mathrm{m}^{2}$ and at this load, the stress of main reinforcement of cross rib equals to $220.6 \%$ of the induced stress of the reinforcement of main rib.

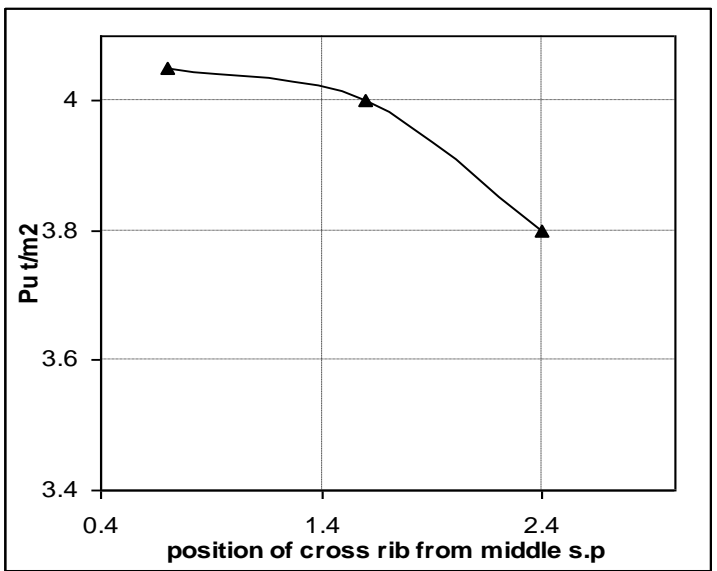

Fig (8) The relationship between position of cross rib and Pu

In addition to that the mode of failure for this slab was compression failure due to the principles stress at the bottom fibber of the connection between the cross rib and the edge solid part. This means that high deformations and stress induced of the cross ribs. And the cross ribs are as elastic supports for the main ribs not just to decrease the deflection of the slab. So the induced deformations and the stress of the cross rib must be taken into account by increasing the cross section and the main reinforcement.

It was observed from investigation Figs 9 that the strains of concrete and stress of steel of the cross rib for slabs I 3 are bigger than the strains and stress of the cross rib in slab I2. The reason of this, as mentioned before as the cross rib approaches from the maximum section of the main ribs, the applied loads on it increase. While in slab I4, the stress and the strains at mid section of cross rib decrease another time. This is because, increase the negative bending moments in slab I4 as mentioned before.

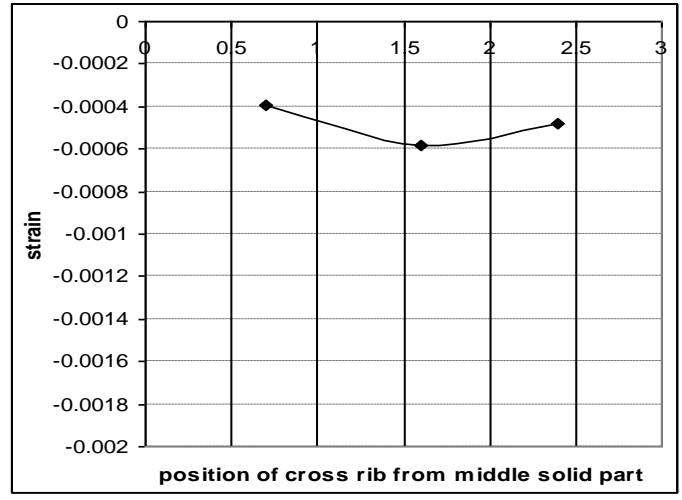

a)- strain of concrete

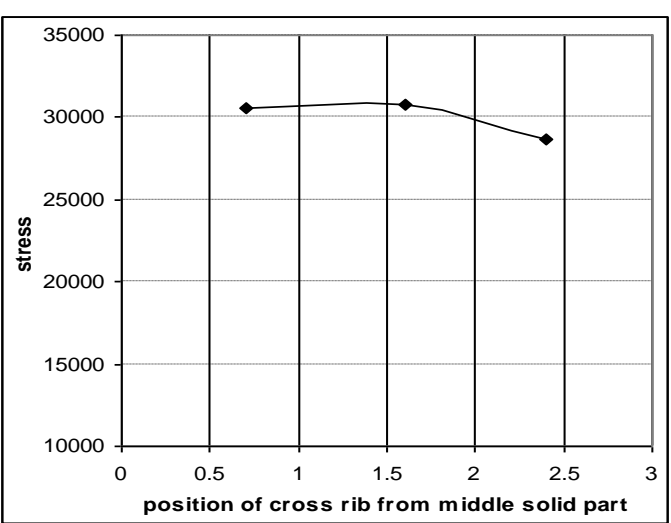

b)- stress of steel

Fig (9) the relation between the maximum strain and stress at mid section of cross rib and the position of cross rib at load $3 \mathrm{t} / \mathrm{m}^{2}$. 

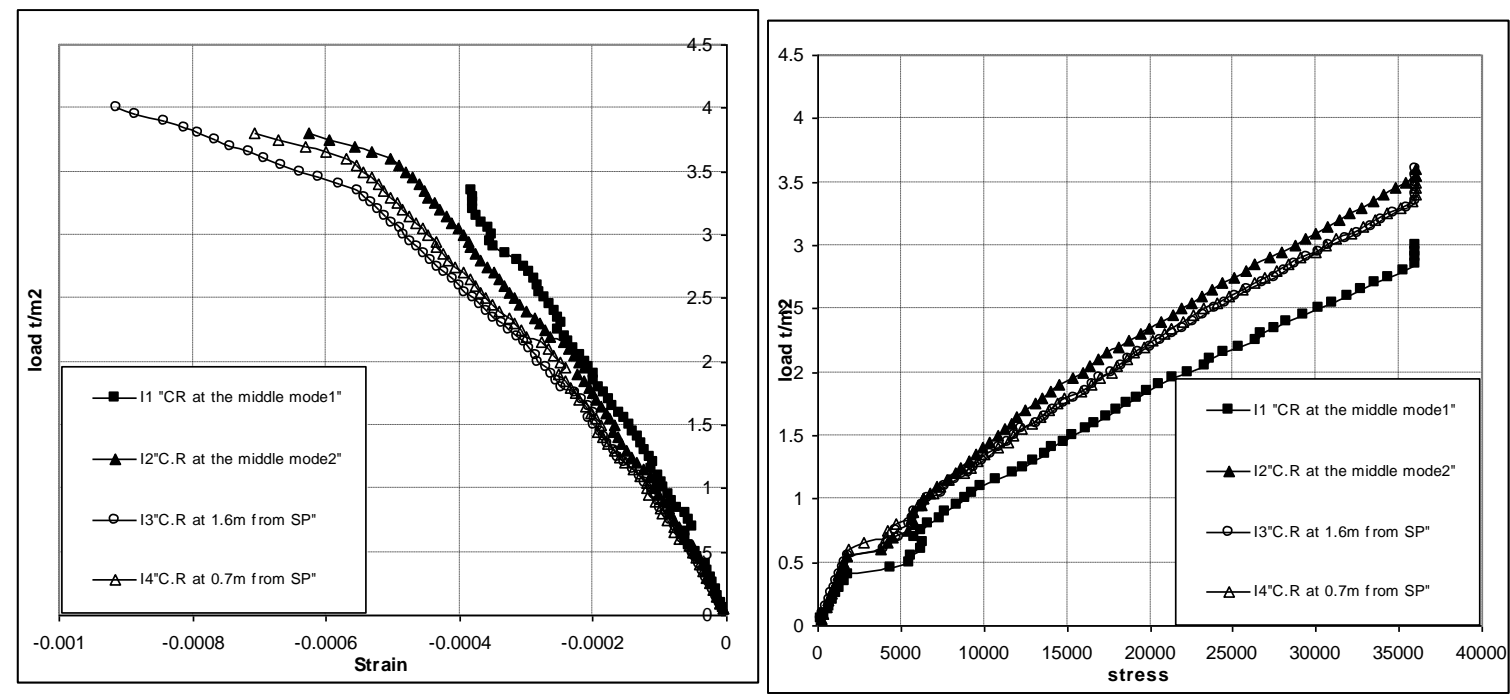

(a) load-strain curve of concrete at top b)load-stress curve of steel at bottom fibers Fig (10) load-strain and stress curve at mid section of the cross ribs

\subsubsection{3)- Deformations and stress of the middle rib.}

The maximum deflection of the middle rib and the relationship between load and deflection are presented in table 3 and shown in Fig 11 respectively.

Table 3 Deformations and stresses at mid section of middle rib

\begin{tabular}{|c|c|c|c|c|c|c|}
\hline slabs & $(\mathrm{Sr})$ & $\left(I_{1}\right)$ & $\left(I_{2}\right)$ & $(13)$ & $(14)$ & \\
\hline slabs of Group (I) & $\begin{array}{l}\text { without } \\
\text { C.R }\end{array}$ & $\begin{array}{l}\text { C. } R \text { in the } \\
\text { middle } \\
\text { mode } 1\end{array}$ & $\begin{array}{l}\text { C. } R \text { in the } \\
\text { middle } \\
\text { mode } 2\end{array}$ & $\begin{array}{l}\text { C.R at } 1.6 \mathrm{~m} \\
\text { from S.P } \\
\text { mode } 2\end{array}$ & $\begin{array}{l}\text { C.R at } 0.7 \\
\text { from } S . P \\
\text { mode } 2\end{array}$ & notes \\
\hline max. deflection $(\mathrm{cm})$ & 4.69 & 3.98 & 4.22 & 4.65 & 4.70 & \multirow{3}{*}{$\begin{array}{l}\text { straining actions at } \\
\text { failure load }\end{array}$} \\
\hline max strain of concrete & $-5.93 E-04$ & $-4.46 \mathrm{E}-04$ & $-6.17 E-04$ & $-4.96 \mathrm{E}-04$ & $-6.17 E-04$ & \\
\hline max stress of steel " $t / \mathrm{m}^{2}$ & 25950.3 & 21916.2 & 26087.24 & 26131.3 & 29912.6 & \\
\hline deflection " cm" & 3.82 & 3.33 & 2.9 & 2.63 & 2.88 & \multirow{3}{*}{$\begin{array}{l}\text { straining actions at } 0.9 \\
\text { the failure load of } \\
\text { reference slab }(3 \mathrm{t} / \mathrm{m} 2)\end{array}$} \\
\hline strain of concrete & $-5.19 E-04$ & $-3.55 E-04$ & $-3.41 E-04$ & $-3.31 \mathrm{E}-04$ & $-4.47 \mathrm{E}-04$ & \\
\hline stress of steel " $\mathrm{t} / \mathrm{m} 2$ " & 22475.9 & 17838.2 & 16860.165 & 16671.9 & 20529.2 & \\
\hline
\end{tabular}

The existence of cross rib decreases the maximum deflection, strains of concrete, stress of steel of the main rib and increases the rigidity of the slabs. It was observed that the maximum deformations and stress of the main rib for slabs I1, I 2 and I3 were at section between the cross rib and the middle solid part while the maximum deformations and stress of the main rib for slab I4 were at section between the cross rib and edge solid part .

The relationship between the load-deformations and stress of the middle rib are shown in Figs 12 to 15.

Comparison between the two slabs $\mathrm{I} 2$ and I3, it was noted that as the cross rib approaches from the middle solid part, the deformations and stress of the main rib decrease. This is because that approaching the cross rib in slab $\mathrm{I} 2$ from the maximum zone of the main rib which lies in-between the mid section of the rib and middle solid part. But in slab I4, the deformations and stress of the main rib increase another time. This is due to increase the span of the rib between the cross rib and edge solid part and the maximum section lies in-between this zone. 
The values of maximum deflection at mid section of middle rib at load equal 0.9 of the ultimate load of reference slab "3.0 t/m ${ }^{2}$ " for slabs I1, I2, I3 and I 4 are $87.2 \%, 75.8 \%, 68.9 \%$ and $75.4 \%$ of the value of maximum deflection of reference slab respectively.

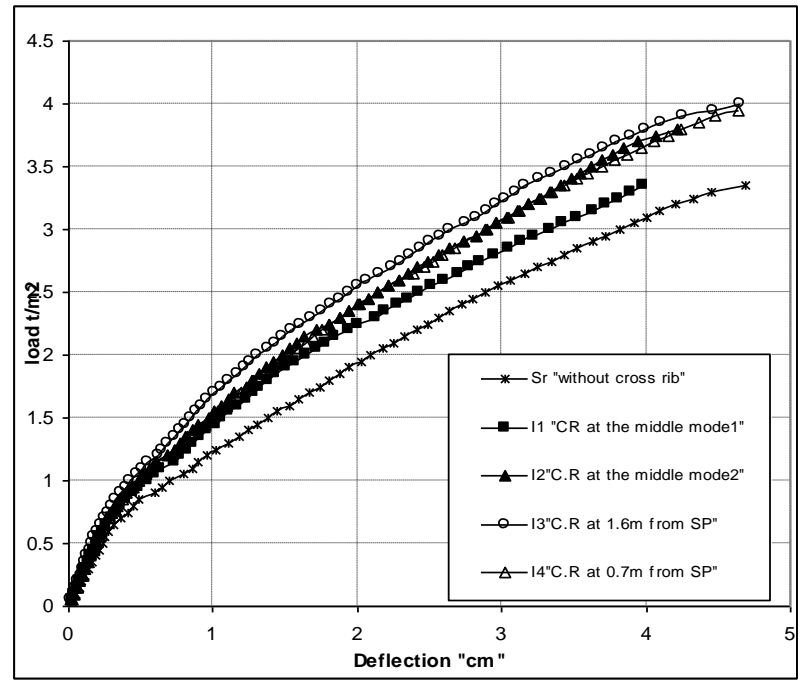

Fig (4.11) The load-deflection curve at mid section of middle rib

The values of strain of concrete at mid section of middle rib at load equal 0.9 of the ultimate load of reference slab "3.0 $\mathrm{t} / \mathrm{m}^{2}$ " for slabs I1, I2, I3 and I4 are $68.5 \%$, $65.7 \%, 63.7 \%$ and $86.3 \%$ the values of strain of concrete for reference slab respectively. And the values of stress of steel at mid section of middle rib for slabs I1, I2, I3 and I4 are $79.4 \%, 75 \%, 74.2 \%$ and $91.3 \%$ the values of stress of steel for reference slab respectively. The maximum strain of concrete and stress of steel at mid section of middle rib are shown in table 3 .

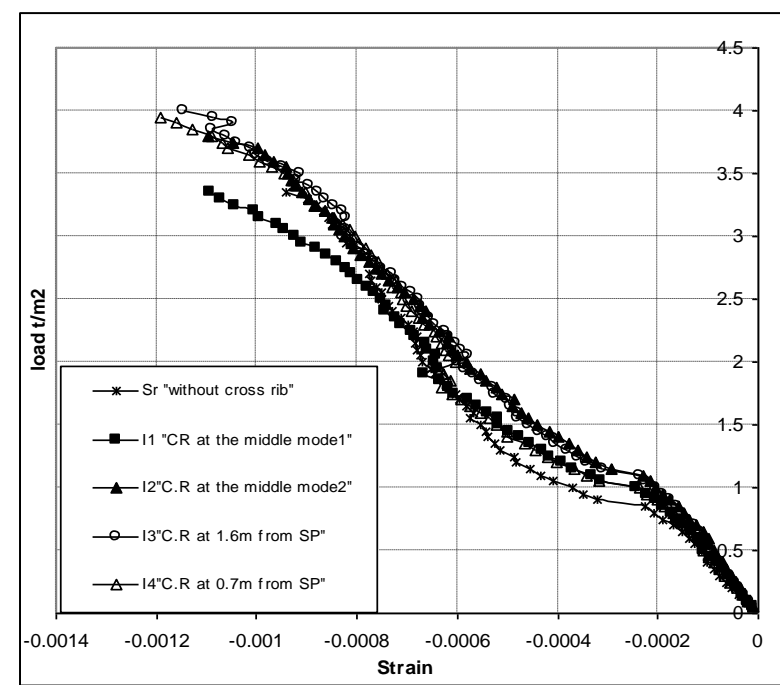

(a) load-strain curve of concrete at bottom fibers

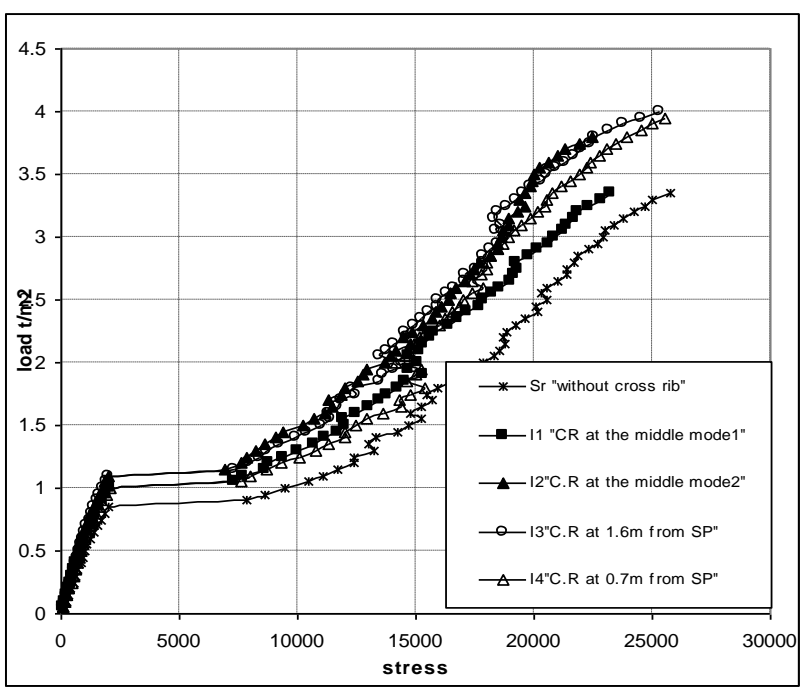

(b) load-stress curve of steel at top fibers

Fig (12) load- strain and stress curve at connection between the rib and edge solid part 

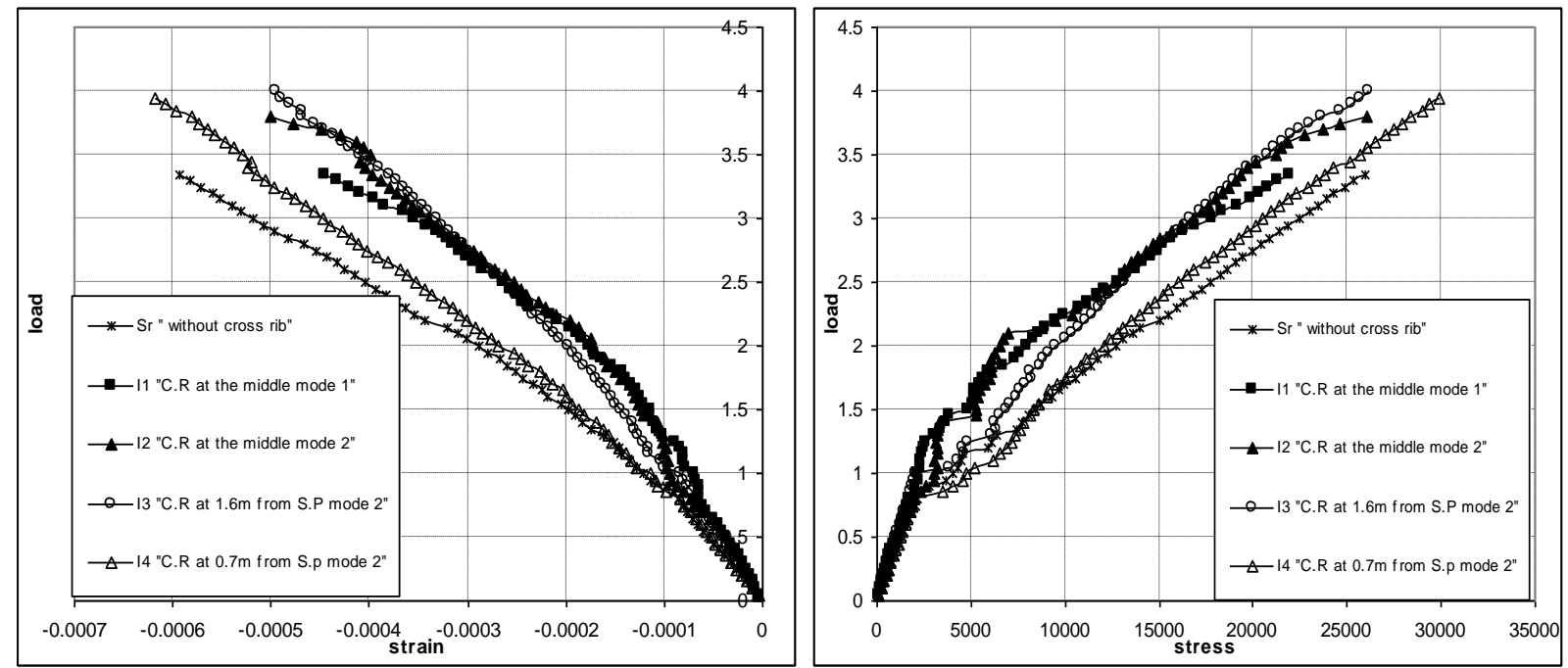

(a) load-strain curve of concrete at top fibers

(b) load-stress curve of steel at bottom fibers Fig (13) load-strain and stress curve mid section

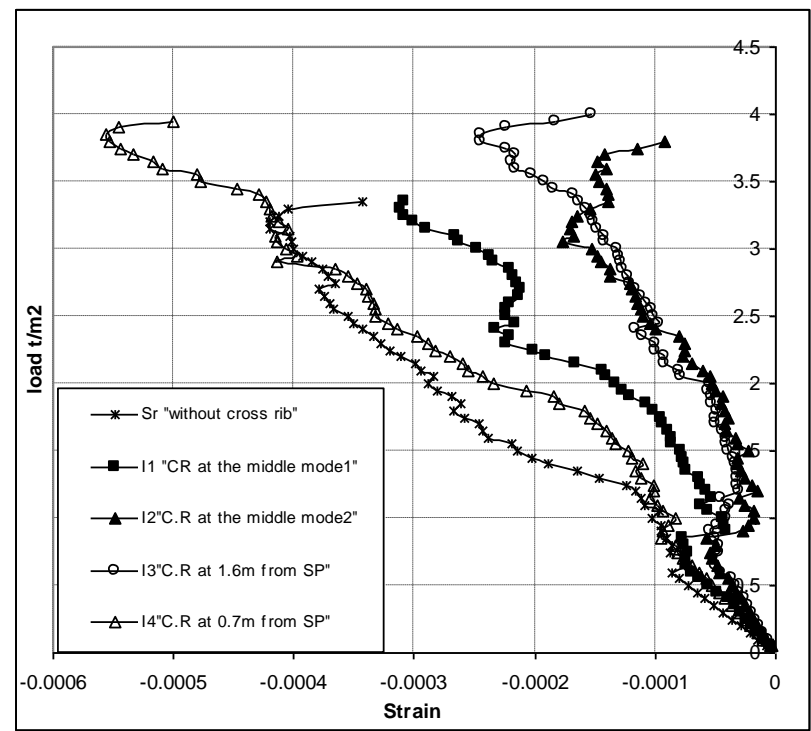

(a) load-strain curve of concrete at bottom fibers

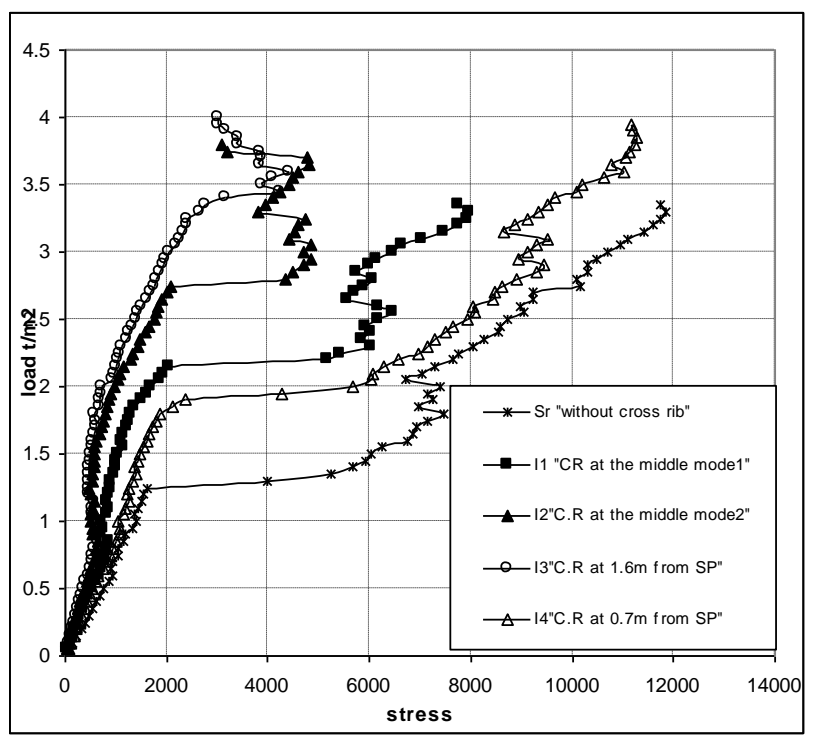

(b) load- stress curve of steel at top fibers

Fig (14) load-strain and stress curve at connection between the rib and middle solid part

The existence of cross rib has small effect on the strains and stress of the connection between the rib and edge solid part while has pronounced effect on the strains and stress at the connection between the rib and middle solid part.

It was noted that the strains and stress at the connection between the rib and middle solid part for slabs I1 and I4 are bigger than other slabs. This is because that for slab I1, the cross section and the main reinforcement of the cross rib were low. So the stiffness of the cross rib was weak and the effect of cross rib as elastic support for the main ribs was smaller than other slabs. While in slab I4, due to approaching the cross rib from middle solid part where the distance was $0.7 \mathrm{~m}$. This leads to high restrain of the length of the rib which between the cross rib and middle solid part and increase the negative bending moments at this connection. 


\subsubsection{4) - Deformations and stresses of the middle solid part .}

The maximum deflection at mid span of solid part and the relationship between load and deflection are presented in table 4 and shown in Fig 15 respectively.

Table 4 Deformations and stresses at mid section of solid part

\begin{tabular}{|c|c|c|c|c|c|c|}
\hline slabs & $(\mathrm{Sr})$ & $\left(\mathrm{I}_{1}\right)$ & $\left(I_{2}\right)$ & $(13)$ & $(14)$ & \\
\hline slabs of Group (I) & $\begin{array}{l}\text { without } \\
\text { C.R }\end{array}$ & $\begin{array}{l}\text { C. } R \text { in the } \\
\text { middle } \\
\text { mode } 1\end{array}$ & $\begin{array}{l}\text { C. } R \text { in the } \\
\text { middle } \\
\text { mode } 2\end{array}$ & $\begin{array}{l}\text { C.R at } 1.6 \mathrm{~m} \\
\text { from S.P } \\
\text { mode } 2\end{array}$ & $\begin{array}{l}\text { C.R at } 0.7 \\
\text { from } S . P \\
\text { mode } 2\end{array}$ & notes \\
\hline max. deflection $(\mathrm{cm})$ & 4.01 & 3.50 & 4.00 & 4.40 & 4.00 & \multirow{3}{*}{$\begin{array}{l}\text { straining actions at } \\
\text { failure load }\end{array}$} \\
\hline max strain of concrete & $-2.15 \mathrm{E}-03$ & $-1.46 E-03$ & $-1.35 E-03$ & $-1.86 E-03$ & $-1.60 E-03$ & \\
\hline max stress of steel " $t / m 2 "$ & 36000 & 34578.15 & 36000 & 36000 & 36000 & \\
\hline deflection " cm" & 3.17 & 2.98 & 2.74 & 2.49 & 2.43 & \multirow{3}{*}{$\begin{array}{l}\text { straining actions at } 0.9 \\
\text { the failure load of } \\
\text { reference slab }(3 \mathrm{t} / \mathrm{m} 2)\end{array}$} \\
\hline strain of concrete & $-8.56 E-04$ & $-8.50 E-04$ & $-6.72 E-04$ & $-6.11 \mathrm{E}-04$ & $-6.00 E-04$ & \\
\hline stress of steel " $\mathrm{t} / \mathrm{m} 2 "$ & 31713.5 & 29274.15 & 27023.963 & 24733.2125 & 23893.225 & \\
\hline
\end{tabular}

The load - strain curve of concrete and the load - stress curve of steel at mid of middle solid part are shown as Figs 16

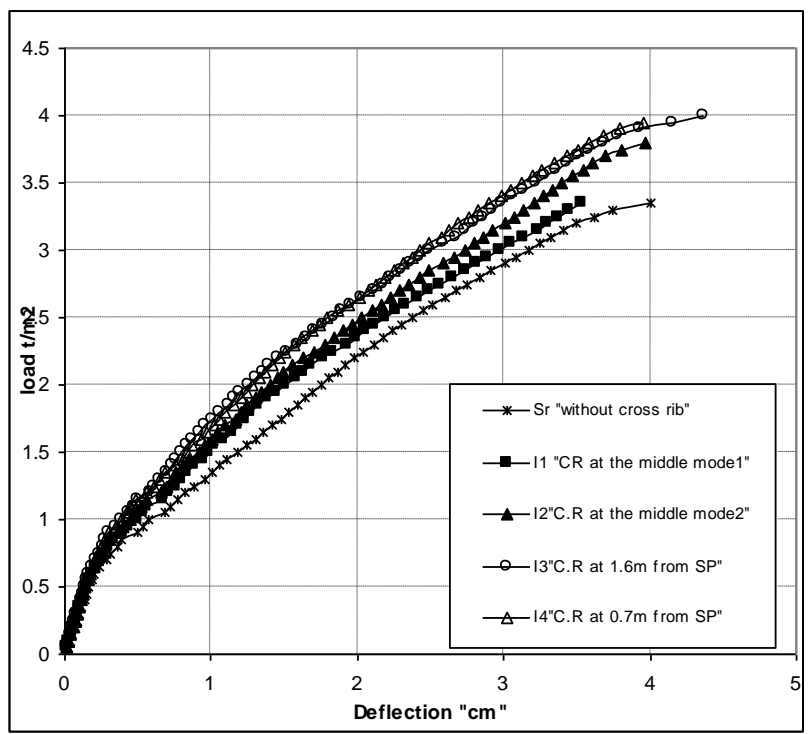

Fig (15) The load-deflection curve at mid span of solid part

From investigation the Figs 15 and 16, it is noted that as the position of cross rib approaches from the middle solid part, the induced deformations and stress at mid section of solid part decrease.

The values of maximum deflection at mid section of solid part at load equal to 0.9 of the ultimate load of reference slab " $3 \mathrm{t} / \mathrm{m}^{2}$ "for slabs for slabs I1, I2, I3 and I4 are $93.9 \%, 86.3 \%, 78.4 \%$ and $76.6 \%$ the value of maximum deflection for reference slab respectively

The values of strain of concrete at mid section of solid part at load equal to 0.9 of the ultimate load of reference slab " $3 \mathrm{t} / \mathrm{m}^{2}$ "for slabs I1, I2, I3 and I4 are $99.3 \%$, $78.5 \%, 71.4 \%$ and $70.1 \%$ the value of strain of concrete for reference slab respectively. And the values of stress of steel at mid section of solid part for slabs I1, I2, I3 and I4 are $92.3 \%, 85.2 \% 77.9 \%$ and $75.3 \%$ the value of stress of steel for reference slab respectively. 

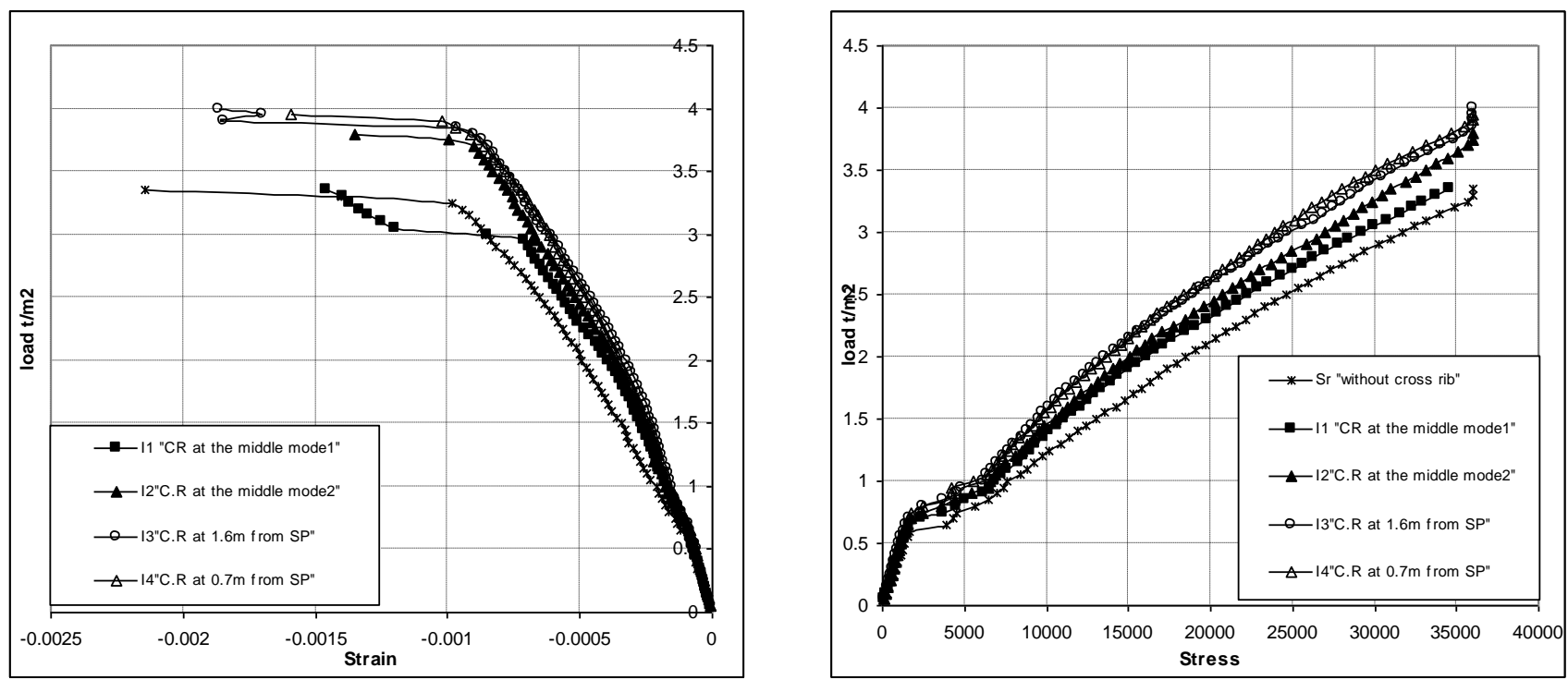

a) load- strain curve of concrete at middle solid part (b) load-stress curve of steel at middle solid part

Fig (16) load-strain and stress curve at mid section of solid part

\subsubsection{The effect of replacing middle solid part with middle beam}

\subsubsection{1)- cracking load, modes of failure and ultimate load.}

However increasing the moment of inertia due to existence middle beam insist of middle solid part, but this has small effect on the cracking load. This is because that the cracking load for the reference slab occurred at the mid section of the middle solid part while the cracking load for slabs $\mathrm{H} 1$ and $\mathrm{H} 2$ occurred at the mid section of the middle rib which has the same depth of middle solid part in the reference slab. The relationship between the thickness of middle support and Pcr is shown in Fig (17)

The final modes of failure for slabs of group " $\mathrm{H}$ " were tension flexural failure caused by yielding of the tension reinforcement of middle beam. The relationship between the thickness of middle support and $\mathrm{Pu}$ is shown in Fig (18). The existence of middle beam has pronounced effect on the ultimate load. Where the failure of slabs sr, $\mathrm{H} 1$ and $\mathrm{H} 2$ occurred at the mid section of the middle support. And because that increasing the moment of inertia of the middle support for slabs $\mathrm{H} 1$ and $\mathrm{H} 2$, the increase of ultimate load for these slabs was clearly and bigger than the reference slab. $\mathrm{Pu}$ of slabs $\mathrm{H} 1$ and $\mathrm{H} 2$ are $123.9 \%$ and $132.8 \%$ Pu of reference slab respectively.
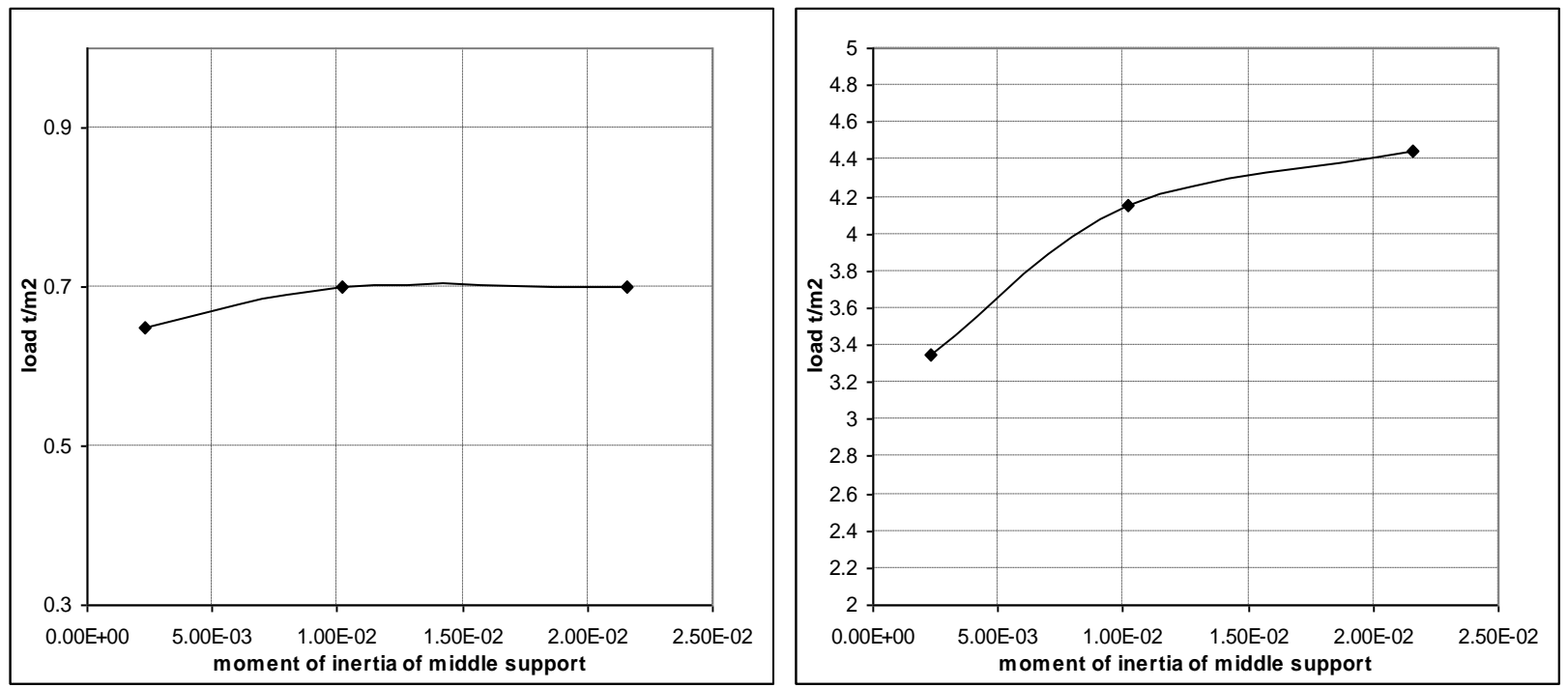

Fig (17) The relationship between moment Fig (18) The relationship between 
of inertia of middle support and Pcr moment of inertia of middle support and Pu

\subsubsection{2)- Deformations and stresses of the middle rib.}

The maximum deflection of the middle rib and the relationship between load and deflection are presented in table 5 and shown in Fig 19 respectively.

Table 5 Deformations and stresses at mid section of middle rib

\begin{tabular}{|c|c|c|c|c|}
\hline slabs & $\mathrm{Sr}$ & $\mathrm{H} 1$ & $\mathrm{H} 2$ & \multirow{2}{*}{ note } \\
\hline thickness of the middle support & solid part with $\mathrm{t}=0.25 \mathrm{~m}$ & beam with $\mathrm{tb}=0.75 \mathrm{~m}$ & beam with $\mathrm{tb}=0.95 \mathrm{~m}$ & \\
\hline max. deflection $(\mathrm{cm})$ & 4.69 & 4.22 & 4.08 & \multirow{3}{*}{$\begin{array}{l}\text { straining actions at } \\
\text { failure load }\end{array}$} \\
\hline max strain of concrete & $-5.93 E-04$ & $-8.07 E-04$ & $-9.59 E-04$ & \\
\hline max stress of steel " $t / m 2 "$ & 25950.3 & 35259.8 & 35827 & \\
\hline deflection " cm" & 3.82 & 2.53 & 2.30 & \multirow{3}{*}{$\begin{array}{l}\text { straining actions at } \\
0.9 \text { the failure load } \\
\text { of reference slab }\end{array}$} \\
\hline strain of concrete & $-5.19 \mathrm{E}-04$ & $-5.48 \mathrm{E}-04$ & $-5.38 \mathrm{E}-04$ & \\
\hline stress of steel " t/m2" & 22475.9 & 23588.6 & 23504 & \\
\hline
\end{tabular}

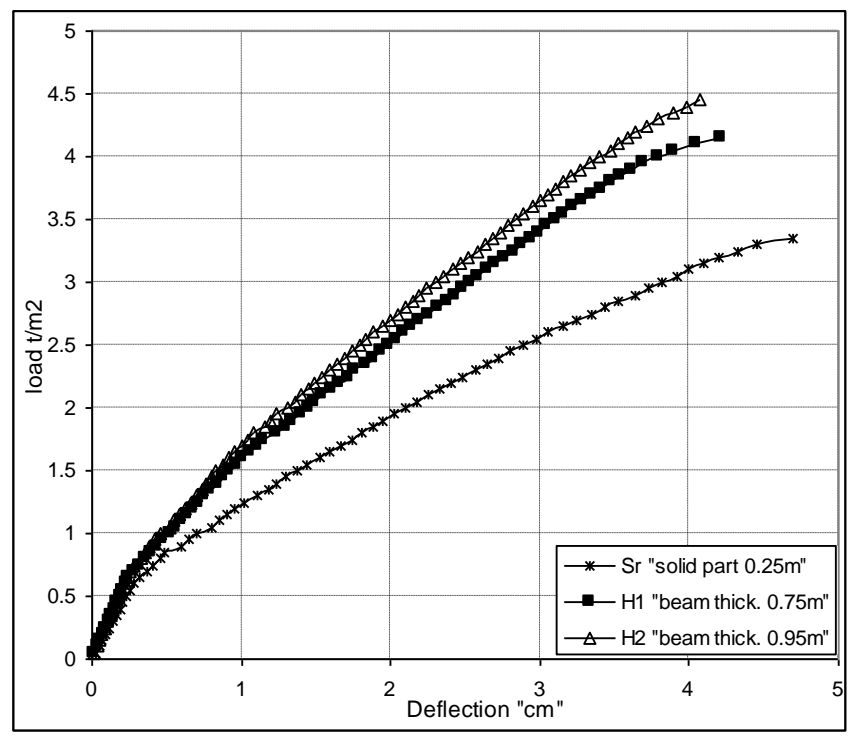

Fig (19) The load - deflection curve at mid section of middle rib

The load deflection curve of group $\mathrm{H}$ shows that the slabs with middle beam have high stiffness comparison with the reference slab which represents the slab with middle solid part. The values of maximum deflection at mid section of middle rib at load equal 0.9 of the ultimate load of reference slab "3.0 t/m " for slabs $\mathrm{H} 1$ and $\mathrm{H} 2$ are $66.3 \%$ and $60 \%$ of the value of maximum deflection of reference slab respectively.

From investigation Figs 20 and 22, it was observed that clear difference was observed of the values of deformations and stresses at the connection zones for slabs $\mathrm{H} 1$ and $\mathrm{H} 2$ comparison with reference slab. This is due to increase the length of the ribs by ratio $10.4 \%$. Also using middle beam in slabs $\mathrm{H} 1$ and $\mathrm{H} 2$ instate of middle solid part increases the rigidity of connection between the rib and middle solid part for these slabs and produces high negative moments.

The values of strain of concrete and stress of steel at mid section of the rib for slabs $\mathrm{H} 1$ and $\mathrm{H} 2$ were higher than their values of reference slab. This is because increasing the length of the ribs in slabs $\mathrm{H} 1$ and $\mathrm{H} 2$. But this increase of the strains and stresses was slightly because the increase of strains and stresses at connection zones between the rib and solid parts. See table 5 


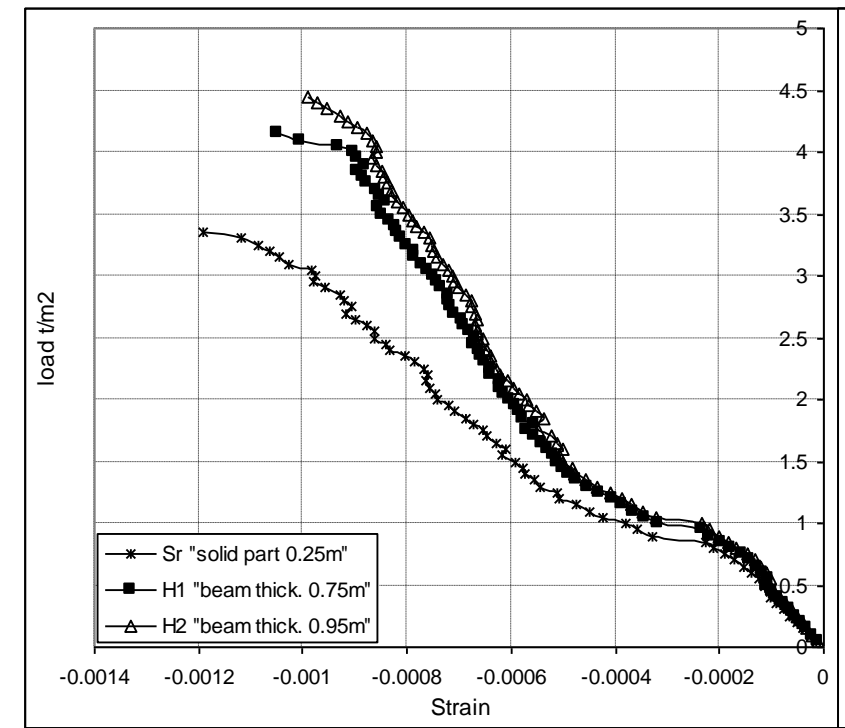

(a) load-strain curve of concrete at bottom fibers

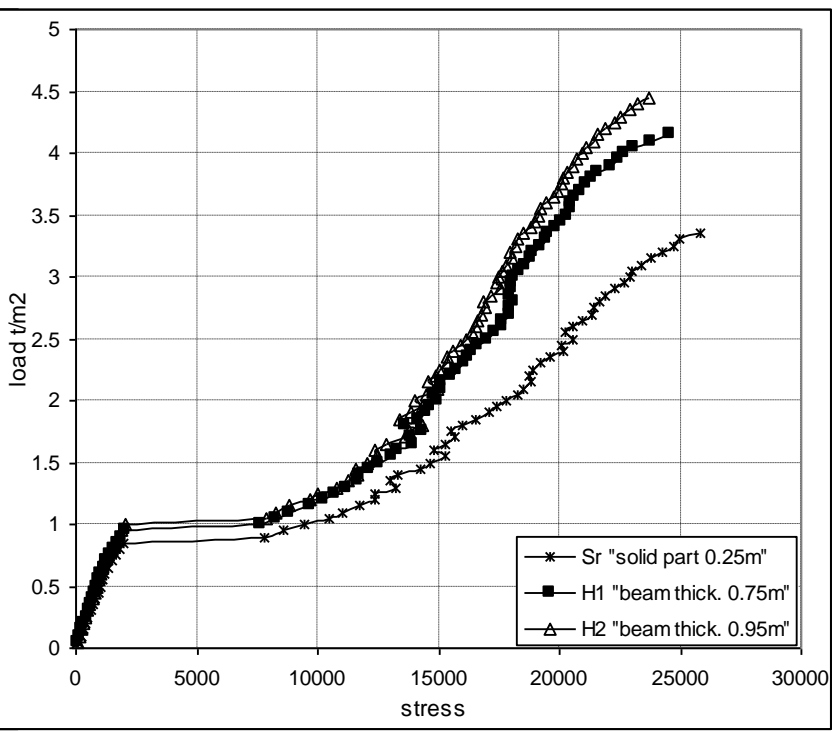

(b) load-stress curve of steel at top fibers

Fig (20) load-strain and stress curve at connection between rib and edge solid part

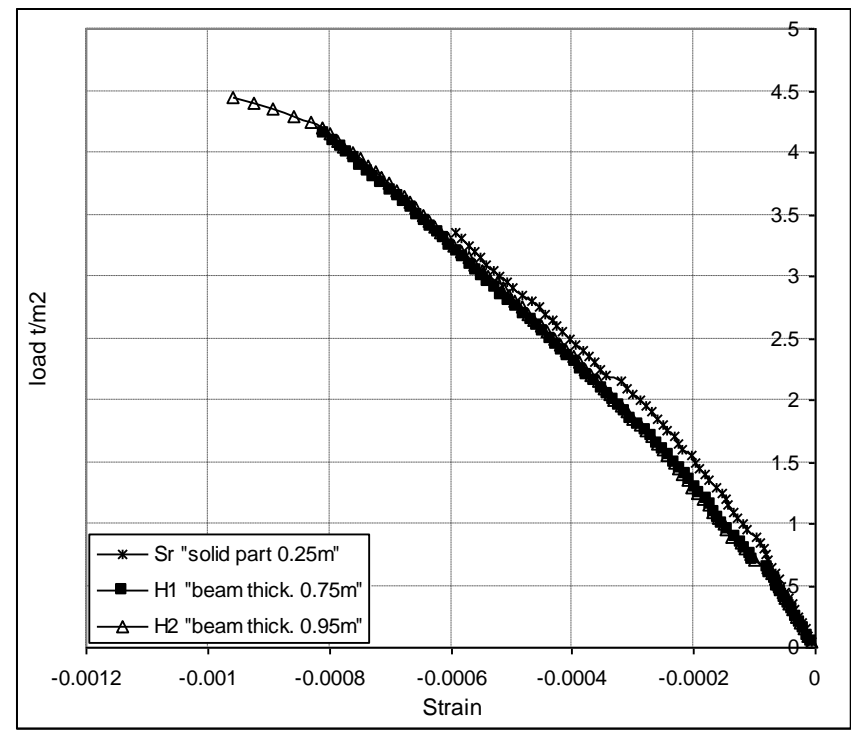

(a) load-strain curve of concrete at top fiber

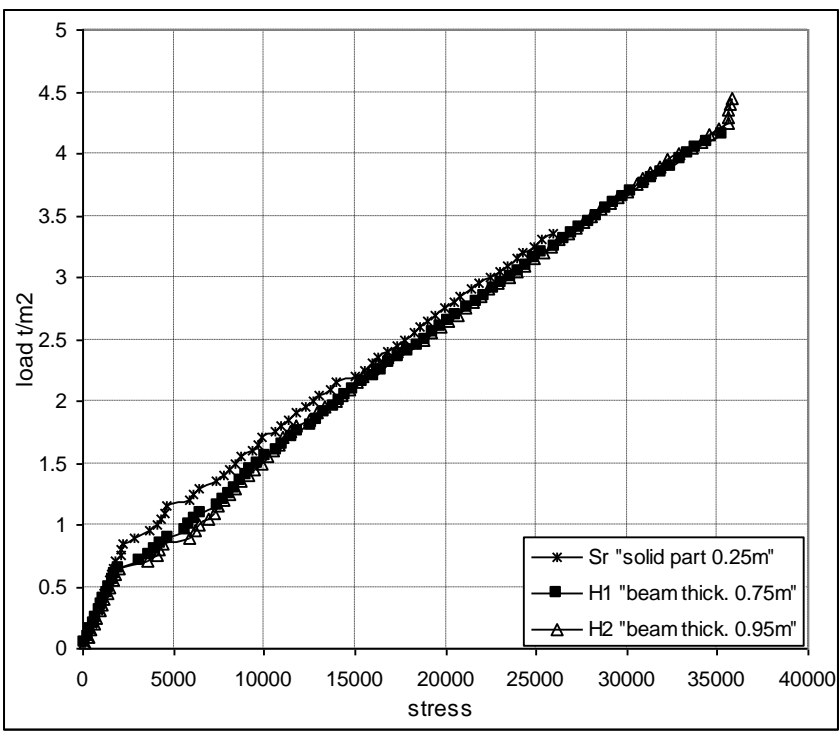

(b) load-stress curve of steel at bottom fibers Fig (21) load- strain and stress curve at middle of rib

It was observed that the slabs with middle beam give best results more than the slabs with middle solid part. In Slabs with middle beam the load capacity was higher and the maximum deflection, the reinforcement steel were lower than the slabs with middle solid part. Table 6 represents comparison between slab H1 as example for slabs with middle beam and reference slab which was with middle solid part.

Where:-

$\Delta W_{s}=\frac{W_{s}-W_{s S r}}{W_{s S r}}, \Delta U_{z}=\frac{U-U_{s r}}{U_{s r}}, \Delta P_{u}=\frac{P_{u}-P_{u S r}}{P_{u S r}}$

$W_{s}=$ weight of reinforcement steel of the middle support for slabs of group $\mathrm{H}$ 
$W_{s s r}=$ weight of reinforcement steel of middle support for reference

$P_{u}=$ ultimate load for slabs of group $\mathrm{H}$

$P_{u S r}=$ ultimate load of reference slab

$U=$ maximum deflection for slabs of group $\mathrm{H}$

$U_{S r}=$ maximum deflection of reference slab

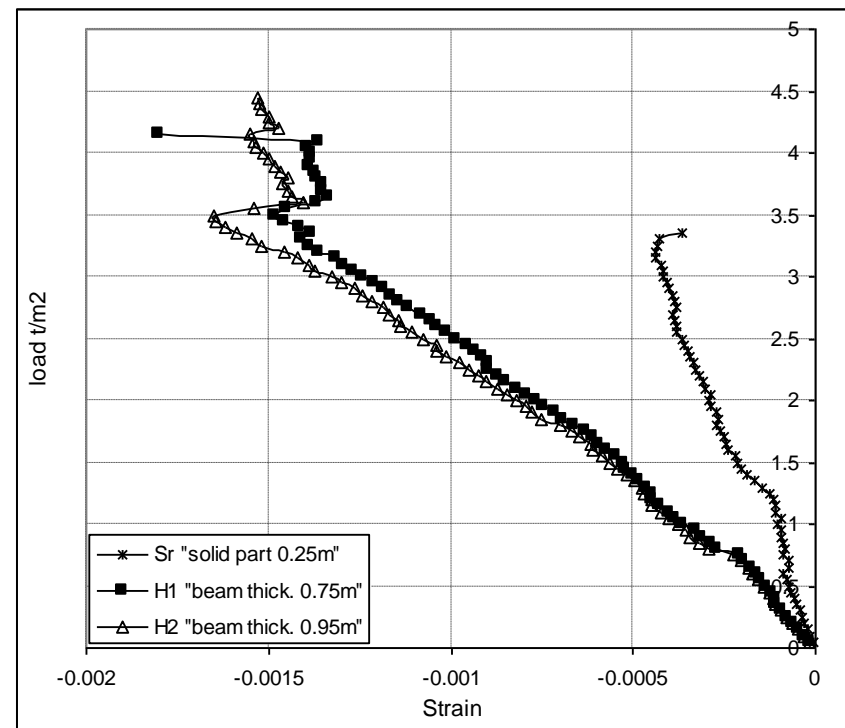

a) load-strain curve of concrete at bottom fibers

Fig (22) load-strain and stress curve

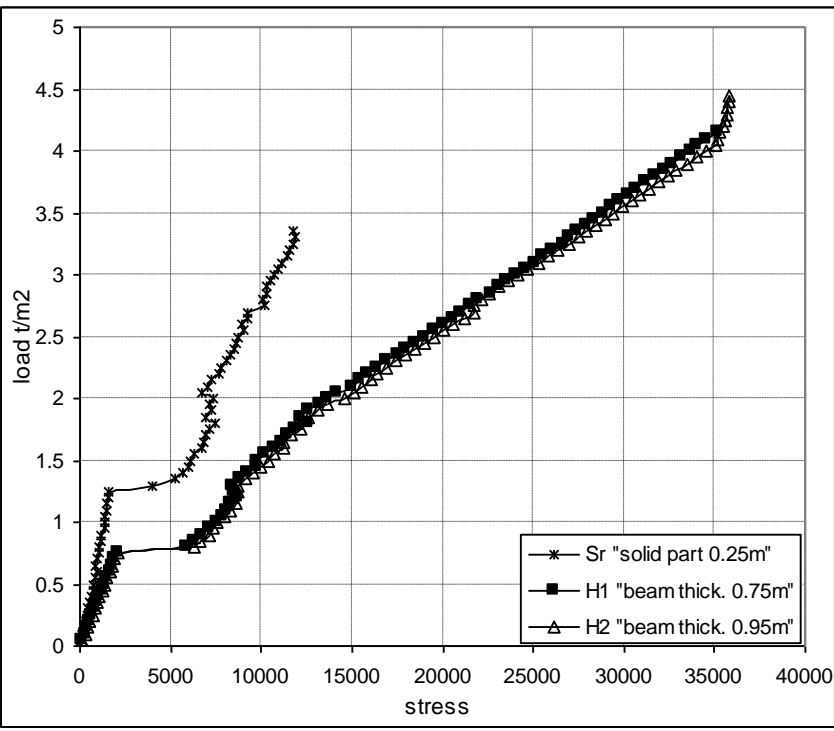

(b) load-stress curve of steel at top fibers

at connection between the rib and middle

beam

Table 6

\begin{tabular}{|c|c|}
\hline slabs & $\mathrm{H} 1$ " beam tb $=0.75 \mathrm{~m} "$ \\
\hline$\Delta \mathrm{Ws} \%$ & $-66 \%$ \\
\hline$\Delta \mathrm{Pu} \%$ & $23.90 \%$ \\
\hline$\Delta \mathrm{Uz} \%$ at load 3 t/m2 & $-33.90 \%$ \\
\hline
\end{tabular}

\section{CONCLUSIONS.}

The following conclusions have been drawn out of the presented study:-

1) - High stresses and deformations induced in the cross ribs. Theses stress and deformations must be taken into consideration.

2) - The cross ribs are as elastic supports for the main ribs and these ribs are not just to decrease the buckling of slab. The existence of cross ribs decreases the induced stresses and deformations in both main rib and solid part.

3) - As the cross rib approaches from the middle solid part, the ultimate load of slabs increases and make the yielding of main reinforcement of the middle solid part to late.

4) - The slabs with middle beam give best results more than the slabs with middle solid part. In Slabs with middle beam the load capacity was higher and the maximum deflection, the reinforcement steel were lower than the slabs with middle solid part 


\section{REFERENCES}

1. Ahmed Abdel-Raheman " Analysis Of Waffle Slabs With Openings" M.Sc.D, Zakazic University 2005.

2. Ahmed M. H., Hassaneen Y. A., Abd El Shafy. Z. E. And Farouk M. A. ( The Effect Of Solid Parts On Non-Linear Of One Way Ribbed Slabs) journal of engineering sciences Assuit, October 2010.

3. American concrete institute (ACI-318-02) 2002.

4. Bangash M.Y.H (Concrete and Concrete Structure: Numerical Modeling and Applications) Elsevier Science Publishers Ltd.,London, England 1989.

5. British Standard Code OF Practice (BS 8110-97) 1997.

6. Cope, R.J., and Clark, L.A, "Concrete slabs: analysis and design " Elsevier applied science publishers, London and New York, 502pp,(1984)

7. Cusens A. R. and Pama . P. "Bridge deck analysis ", $1^{\text {st }}$ Ed., Wiley, England. 1975

8. Desayi, P and Krishnan, S (Equation for the Stress-Strain Curve of Concrete ) Journal of the American concrete institute, 61, pp.345-350, March 1964.

9. Egyptian code for design and construction of reinforcement concrete structures . ECP 203,2007

10. Gere, J .M and Timoshenko, S.P.(Mechanics of Materials)PWS publishing company, Boston , Massachusetts, 1997.

11. Sahah, S.P., Swartz, S.E. and Ouyang, C. (Fracture Mechanics of Concrete)John Wily \&Sons,Inc. New York, 1995.

12. Shaker El-Behairy (Reinforced Concrete Design Handbook) ,Ain Shams University, Sixth Edition,2004.

13. Soghair H.M, Aly. A.G, Ahmed M.H and Farouk M.A, (Structural Analysis Of Ribbed Slabs) journal of engineering sciences Assuit, march 2008 